\title{
Seroprevalence of sheep and goat brucellosis in the northeast of Portugal
}

\author{
Seroprevalencia de brucelosis ovina y caprina en el nordeste de Portugal
}

\author{
AM Coelho ${ }^{\mathrm{a}}$, AC Coelho ${ }^{\mathrm{b}^{*}}$, J Rodrigues ${ }^{\mathrm{b}}$ \\ ${ }^{a}$ Veterinary Services of the North, Division of Veterinary Intervention of Vila Real, Corgo Nucleus, Vila Real, Portugal. \\ ${ }^{\mathrm{b}}$ Veterinary Microbiology Laboratory, Department of Veterinary Sciences, University of Trás-os-Montes and Alto Douro, \\ Vila Real, Portugal.
}

\begin{abstract}
RESUMEN
Se realizó una encuesta para estimar la seroprevalencia de brucelosis ovina y caprina en la región de Trás-os-Montes e Alto Douro, al noreste de Portugal. En total fueron analizados 278.097 pequeños rumiantes distribuidos en 5.466 rebaños pertenecientes a 13 organizaciones de Ganaderos (OPP) fueron analizados. Cuatrocientos ochenta y siete $(8,9 \%)$ rebaños tenían uno o más animales serológicamente positivos, con valores que oscilaban entre $8,2 \%$ y $9,7 \%$. La prevalencia individual fue de $0,44 \%$ (IC $95 \%$ 0,40-0,48\%). No se detectaron diferencias estadísticamente significativas asociadas al tamaño de los rebaños, las especies, la constitución del rebaño, el tipo de producción y la OPP. Basándose en los resultados de esta encuesta, un pequeño porcentaje de animales y un alto porcentaje de los rebaños en el noreste de Portugal fueron serológicamente positivos. Dada la escasez de estudios epidemiológicos sobre la brucelosis en el norte de Portugal, la información sobre la seroprevalencia obtenida en este estudio es importante a la hora de definir medidas de control de la brucelosis en la zona.
\end{abstract}

Palabras clave: Brucella melitensis, pequeños rumiantes, epidemiología, seroprevalencia.

\section{SUMMARY}

A survey to estimate the seroprevalence of ovine and caprine brucellosis was conducted in the region of Trás-os-Montes e Alto Douro, Northeast of Portugal. In total, 278,097 small ruminants and 5,466 flocks from 13 Livestock Farmers Organizations (OPP's) were analysed. Four hundred and eighty seven (8.9\%) flocks had one or more serologically positive animals with values ranging between $8.2 \%$ and $9.7 \%$. The individual seroprevalence was 0.44\% (CI 95\% 0.40-0.48\%). There were significant differences in seroprevalence rates among herd sizes, species, constitution of herd, production's type and OPP. Based on the results of this survey, a small percentage of animals and a high percentage of flocks in the Northeast of Portugal were serologically positive. Considering the paucity of epidemiological reports on brucellosis in the Northeast of Portugal the information on seroprevalence provided in this study is necessary to define control measures for brucellosis in the area.

Key words: Brucella melitensis, small ruminants, epidemiology, seroprevalence.

\section{INTRODUCTION}

Brucella melitensis occurs naturally in sheep and goats and is highly pathogenic for humans, causing one of the most serious zoonosis in the world. The disease is responsible for considerable economical losses to the small ruminant industry (Benkirane 2006, OIE 2009¹). Sheep and goats brucellosis is endemic in most countries of the Mediterranean basin, the Middle East and Central Asia (Omer et al 2000, Al-Majali et al 2005), Latin America, and parts of Africa (Benkirane 2006). The first report of brucellosis in Portugal is from 1873. An eradication programme was initiated in Portugal, in 1990, in small ruminants, with the financial support of the European Commission. This programme was based on test and slaughter policy, using Rose Bengal Test (RBT)

Accepted: 29.11.2012.

* 5001-801 Vila Real, Portugal; accoelho@utad.pt and Complement Fixation Test (CFT) and the farmers received compensation for the slaughtered animals. A new program of control and eradication started in Portugal with flock vaccination during 2001 - 2004 with the live Brucella melitensis reversion 1 strain vaccine (Rev. 1 vaccine, conjunctival route and dose of $1 \times 10^{9}$ ), and continued the following years with vaccination of young replacements (Neto and Vaz 2002). Traditionally, brucellosis diagnosis was based in the detection of circulating antibodies followed by bacteria isolation of the microorganisms (Cassataro et al 2004, O'Leary et al 2006). Bacteriological diagnosis has lack of sensitivity, and is not a practical and reliable means for diagnosis in largescale programs (Cassataro et al 2004, Garin-Bastuji et al 2006). These limitations make serology the most useful epidemiological tool for laboratory diagnosis of Brucella infection (Erdenebaater et al 2004, Nielsen et al 2002). The RBT and the CFT are the most widely used tests for diagnosis of Brucella melitensis infection and are the 
only prescribed tests (OIE 2009). Usually, the RBT is used as a screening test and CFT as a confirmatory test. Both tests are based in an antigen reaction of the entire cells of Brucella and the antibodies produced as response of infection (OIE 2009).

The present status of the disease in the region of Trásos-Montes e Alto Douro is not well defined causing concern among health technicians. The aim of this study was to estimate seroprevalence of brucellosis in small ruminants considering the paucity of epidemiological reports on brucellosis in the Northeast of Portugal.

\section{MATERIAL AND METHODS}

\section{STUDY AREA}

Animals and flocks were located in Northeast of Portugal, which included 33 counties, in the region of Trásos-Montes and Alto Douro. This region, with a total area of $12,285 \mathrm{~km}^{2}$ is limited on the North and East side by Spain, on the South by the region of Beira Interior and on the West by the regions of Minho and Douro Litoral. The region is crossed from East to West by Douro River with a maximum altitude of $1,415 \mathrm{~m}$ above sea level. The monthly average temperature is over $8{ }^{\circ} \mathrm{C}$ to $16^{\circ} \mathrm{C}$ and it presents 20 days per year of frost and 69 to $80 \%$ of humidity, a precipitation of $400 \mathrm{~mm}$ to $1,800 \mathrm{~mm}$, and 50 to $60 \%$ of insulation per year.

\section{FLOCKS AND ANIMALS}

A cross-sectional epidemiological study was carried out between January and December 2007 to determine seroprevalence of brucellosis. The study population consisted of all animals and flocks registered in the region. Complete information about sanitary interventions (vaccination with Rev. 1), seropositivity, herd size, species, herd constitution (with one species or both), and type of production (meat or milk) was available for all the animals and herds included in this study. Animals vaccinated with Rev. 1 less than 12 months ago were not tested for brucellosis infection and were not included in the study. Flocks or animals without all this information or with contradictory results (e.g. more seropositive animals than animals' interventions) were also excluded. Some herds had one or more sanitary intervention (blood sampling) per year. Only the first intervention was counted for animals and flocks, except in the cases where the next sanitary intervention revealed positive animals, in order not to repeat the information. In total, 41 flocks and 14,091 animals were excluded from the study.

According to the number of adult animals in each flock, flocks were sorted into three different size strata: small ( $\leq 30$ animals), medium ( $>30$ and $\leq 150$ animals), and large (more than 150 animals). A flock was classified as a sheep or goat herd, if having more than $50.0 \%$ of the predominant species, and meat or milk flock if having more than $50.0 \%$ animals producing meat or milk. The herd was considered pure if it had only one species (sheep or goats) and mixed if it had at least two animals of different species.

Of the 5,466 flocks tested 2,985 were classified as small (54.6\%), 2,078 were medium (38.0\%) and 403 were large $(7.4 \%)$, respectively. Most flocks had ovine species $(4,220 ; 77.2 \%)$, and 1,246 were of caprine species $(22.8 \%)$. Regarding herd constitution, 4,599 were pure (one species) $(84.1 \%)$ and $867(15.9 \%)$ were of mixed species (both species). About 4,843 of the flocks were of meat type production (88.6\%) and 623 were of milk type (11.4\%). Out of the 278,097 animals tested, 33,849 were from small flocks $(12.2 \%), 159,328$ were from medium flocks $(57.3 \%)$ and 84,920 were from large flocks $(30.5 \%)$, respectively. The majority of specimens surveyed were sheep $(226,799 ; 81.6 \%)$ and 51,298 were goats $(18.5 \%)$ and 218,191 of tested animals were pure $(78.5 \%)$ and $59,906(21.5 \%)$ were mixed species. The majority of animals tested 231,141 were of meat type production $(83.1 \%)$, and 46,956 were of milk type (16.9\%). The proportions of flocks and animals in each category are shown in tables 1 and 3 .

Distribution of animals among the 13 Livestock Farmers Organizations (OPP) is presented in table 4. Each OPP has different criterion for classification of flocks and animals according to brucellosis prevalence in each area of influence.

\section{SAMPLE COLLECTION}

Blood samples from Portuguese small ruminants submitted to the laboratory of Health Service in Mirandela, Portugal were tested serologically by Rose Bengal plate agglutination test (RBT) and/or the complement fixation test (CFT) as described by Alton et al (1988). In RBT, any visible reaction of agglutination is considered to be positive. In CFT sera giving a titer equivalent to 20 ICF$\mathrm{TU} / \mathrm{ml}$ or more are considered to be positive (OIE 2009). The RBT has a sensitivity of approximately $77 \%$ (Alton et al 1988) and a specificity between $90-100 \%$. The CFT has a sensitivity of approximately $88 \%$ and a specificity around $100 \%$ (Garin-Bastuji et al 2006).

Samples were obtained during the Annual Official Brucellosis Eradication Campaign from January to December of 2007, from all small ruminants non-vaccinated, or lambs and kids vaccinated more than 12 months ago.

In non-free brucellosis herds, all animals were first tested with RBT, and animals testing negative were then tested with CFT. Animals were classified as positive if RBT or CFT were positive (parallel testing resulting in increased sensitivity). In free or officially free brucellosis flocks, animals were classified as positive if both RBT and CFT were positive (serial testing resulting in increased specificity). 
Table 1. Seroprevalence of flocks with sheep and goats brucellosis infection by herd size, species, constitution of herd and production type. Seroprevalencia de los rebaños de ovejas y cabras infectadas con brucelosis en relación al tamaño, especies, constitución y tipo de producción.

\begin{tabular}{|c|c|c|c|c|c|}
\hline & $\begin{array}{c}\text { Flocks } \\
\text { tested (n) }\end{array}$ & $\begin{array}{l}\text { Relative distribution } \\
(\%)\end{array}$ & Seropositive & $\begin{array}{c}\text { Prevalence } \\
(\%)\end{array}$ & CI 95\% \\
\hline Herd size & & & $\mathrm{P}<0.001$ & & \\
\hline$\leq 30$ animals & 2,985 & 54.6 & 72 & 2.4 & $1.9-3.0$ \\
\hline$>30$ and $\leq 150$ animals & 2,078 & 38.0 & 323 & 15.5 & $14.0-17.1$ \\
\hline$>150$ animals & 403 & 7.37 & 92 & 22.8 & $18.7-26.9$ \\
\hline Total & 5,466 & 100 & 487 & 8.9 & $8.2-9.7$ \\
\hline Species & & & $\mathrm{P}=0.909$ & & \\
\hline Ovine & 4,220 & 77.2 & 377 & 8.9 & $8.1-9.8$ \\
\hline Caprine & 1,246 & 22.8 & 110 & 8.8 & $7.3-10.4$ \\
\hline Total & 5,466 & 100 & 487 & 8.9 & $8.2-9.7$ \\
\hline Constitution of herd & & & $\mathrm{P}<0.001$ & & \\
\hline Pure (one species) & 4,599 & 84.1 & 372 & 8.1 & $7.3-8.9$ \\
\hline Mixed (both species) & 867 & 15.9 & 115 & 13.3 & $11.0-15.5$ \\
\hline Total & 5,466 & 100 & 487 & 8.9 & $8.2-9.7$ \\
\hline Production type & & & $\mathrm{P}=0.502$ & & \\
\hline Meat & 4,843 & 88.6 & 427 & 8.8 & $8.0-9.6$ \\
\hline Milk & 623 & 11.4 & 60 & 9.6 & $7.3-12.0$ \\
\hline Total & 5,466 & 100 & 487 & 8.9 & $8.2-9.7$ \\
\hline
\end{tabular}

Table 2. Seroprevalence of flocks with sheep and goats brucellosis infection by OPP. Seroprevalencia de los rebaños de ovejas y cabras infectadas con brucelosis por OPP.

\begin{tabular}{|c|c|c|c|c|c|}
\hline & $\begin{array}{l}\text { Animals } \\
\text { tested (n) }\end{array}$ & $\begin{array}{c}\text { Relative distribution } \\
(\%)\end{array}$ & Seropositive & $\begin{array}{c}\text { Prevalence } \\
(\%)\end{array}$ & CI $95 \%$ \\
\hline OPP & & & $\mathrm{P}<0.001$ & & \\
\hline Torre de Moncorvo & 316 & 5.8 & 26 & 8.2 & $5.2-11.3$ \\
\hline Chaves & 603 & 11.0 & 89 & 14.8 & $11.9-17.6$ \\
\hline Vila Pouca de Aguiar & 893 & 16.3 & 79 & 8.9 & $8.3-9.4$ \\
\hline Montalegre & 373 & 6.8 & 40 & 10.7 & $7.6-13.9$ \\
\hline Macedo de Cavaleiros & 832 & 15.2 & 61 & 7.3 & $5.6-9.1$ \\
\hline Boticas & 168 & 3.1 & 18 & 10.7 & $6.0-15.4$ \\
\hline Vinhais & 220 & 4.0 & 18 & 8.2 & $4.6-11.8$ \\
\hline Moimenta da Beira & 328 & 6.0 & 18 & 5.5 & $3.0-8.0$ \\
\hline Tarouca & 561 & 10.3 & 24 & 4.3 & $2.6-6.0$ \\
\hline Miranda e Vimioso & 328 & 6.0 & 14 & 4.3 & $2.1-6.4$ \\
\hline Carrazeda e Vila Flor & 181 & 3.3 & 27 & 14.9 & $9.7-20.1$ \\
\hline Mogadouro & 281 & 5.1 & 18 & 6.4 & $3.6-9.3$ \\
\hline Bragança & 382 & 7.0 & 55 & 14.4 & $10.9-17.9$ \\
\hline Total & 5,466 & 100 & 487 & 8.9 & $8.2-9.7$ \\
\hline
\end{tabular}

\section{DATA ANALYSIS}

Chi-square $\left(\chi^{2}\right)$ tests were used to compare seroprevalence values relatively to OPP's area, herd size, species, herd constitution: pure or mixed, and type of production, individually and per flocks. Analyses were performed with MS Access and SPSS 16.0 software for Windows (SPSS Inc, Chicago IL, USA) considering 0.05 as the level of significance $(\mathrm{P})$. For the proportions, the $95 \%$ confidence interval (CI) was estimated using the exact binomial test.

\section{RESULTS}

A total of 5,466 flocks and 278,097 animals were analysed. One thousand two hundred and thirty six animals $(0.44 \%, 95 \%$ CI: 0.40-0.48) were seropositive. Brucellosis seropositive animals (one or more) were detected in 487 flocks $(8.9 \%, 95 \%$ CI: 8.2-9.7\%).

Table 1 summarizes the proportion of positive flocks per herd size, species, constitution of herd, type of production. Herd size and constitution of herd had signifi- 
Table 3. Individual seroprevalence of sheep and goats brucellosis infection by herd size, species, constitution of herd and production type. Seroprevalencia individual de ovejas y cabras infectadas con brucelosis por tamaño, especies, constitución y tipo de producción.

\begin{tabular}{|c|c|c|c|c|c|}
\hline & $\begin{array}{l}\text { Animals } \\
\text { tested }(\mathrm{n})\end{array}$ & $\begin{array}{c}\text { Relative distribution } \\
\qquad(\%)\end{array}$ & Seropositive & $\begin{array}{c}\text { Prevalence } \\
(\%)\end{array}$ & CI $95 \%$ \\
\hline Herd size & \multicolumn{5}{|c|}{$\mathrm{P}<0.001$} \\
\hline$\leq 30$ animals & 33,849 & 12.2 & 126 & 0.37 & $0.31-0.44$ \\
\hline$>30$ and $\leq 150$ animals & 159,328 & 57.3 & 793 & 0.50 & $0.47-0.53$ \\
\hline$>150$ animals & 84,920 & 30.5 & 317 & 0.37 & $0.33-0.41$ \\
\hline Total & 278,097 & 100 & 1,236 & 0.44 & $0.40-0.48$ \\
\hline Species & \multicolumn{5}{|c|}{$\mathrm{P}<0.001$} \\
\hline Ovine & 226,799 & 81.55 & 852 & 0.38 & $0.35-0.41$ \\
\hline Caprine & 51,298 & 18.45 & 384 & 0.75 & $0.68-0,82$ \\
\hline Total & 278,097 & 100.00 & 1,236 & 0.44 & $0.40-0.48$ \\
\hline Constitution of herd & \multicolumn{5}{|c|}{$\mathrm{P}<0.001$} \\
\hline Pure (one species) & 218,191 & 78.46 & 810 & 0.37 & $0.34-0.40$ \\
\hline Mixed (both species) & 59,906 & 21.54 & 426 & 0.71 & $0.64-0.78$ \\
\hline Total & 278,097 & 100.00 & 1,236 & 0.44 & $0.40-0.48$ \\
\hline Production type & \multicolumn{5}{|c|}{$\mathrm{P}<0.001$} \\
\hline Meat & 231,141 & 83.12 & 1,068 & 0.46 & $0.43-0.49$ \\
\hline Milk & 46,956 & 16.88 & 168 & 0.36 & $0.31-0.41$ \\
\hline Total & 278,097 & 100.00 & 1,236 & 0.44 & $0.40-0.48$ \\
\hline
\end{tabular}

Table 4. Individual seroprevalence of sheep and goats brucellosis infection by OPP. Seroprevalencia individual de ovejas y cabras infectadas con brucelosis por OPP.

\begin{tabular}{|c|c|c|c|c|c|}
\hline & $\begin{array}{c}\text { Animals } \\
\text { tested }(\mathrm{n})\end{array}$ & $\begin{array}{l}\text { Relative distribution } \\
(\%)\end{array}$ & Seropositive & $\begin{array}{c}\text { Prevalence } \\
(\%)\end{array}$ & CI $95 \%$ \\
\hline OPP & & & $\mathrm{P}<0.001$ & & \\
\hline Torre de Moncorvo & 24,850 & 8.94 & 57 & 0.23 & $0.17-0.29$ \\
\hline Chaves & 29,242 & 10.51 & 147 & 0.50 & $0.42-0.58$ \\
\hline Vila Pouca de Aguiar & 27,714 & 9.97 & 317 & 1.14 & $1.02-1.26$ \\
\hline Montalegre & 13,239 & 4.76 & 62 & 0.47 & $0.35-0.65$ \\
\hline Macedo de Cavaleiros & 48,321 & 17.38 & 150 & 0.31 & $0.35-0.46$ \\
\hline Boticas & 6,453 & 2.32 & 51 & 0.79 & $0.57-1.01$ \\
\hline Vinhais & 15,374 & 5.53 & 39 & 0.25 & $0.16-0.32$ \\
\hline Moimenta da Beira & 10,628 & 3.82 & 54 & 0.51 & $0.37-0.65$ \\
\hline Tarouca & 6,710 & 2.41 & 102 & 1.52 & $1.23-1.81$ \\
\hline Miranda e Vimioso & 32,571 & 11.71 & 25 & 0.08 & $0.05-0.11$ \\
\hline Carrazeda e Vila Flor & 12,520 & 4.50 & 54 & 0.43 & $0.32-0.54$ \\
\hline Mogadouro & 19,304 & 6.94 & 41 & 0.21 & $0.15-0.27$ \\
\hline Bragança & 31,171 & 11.21 & 137 & 0.44 & $0.37-0.51$ \\
\hline Total & 278,097 & 100.00 & 1,236 & 0.44 & $0.40-0.48$ \\
\hline
\end{tabular}

cant differences $(\mathrm{P}<0.001)$, but species and production type had no statistical differences $(\mathrm{P}=0.909$ and $\mathrm{P}=$ 0.502 , respectively). Seroprevalence in flocks with 150 or more animals $(22.8 \%)$ was higher than in flocks with more than 30 and less than 150 animals (15.5\%) and even more than the flocks with 30 or less animals $(2.4 \%)$. The seroprevalence of sheep and goats flocks was not significantly different $(\mathrm{P}=0.909)$. The flock production type seroprevalence was not significant $(\mathrm{P}=0.502)$ with a seroprevalence of $8.8 \%$ in meat flocks and $9.6 \%$ in milk flocks. On the other hand, with regards to constitution, mixed herds presented higher values of infection $(13.3 \%)$, than flocks with only one specie $(8.1 \%)$, with differences $(\mathrm{P}<0.001)$. 
Serologically positive sheep and goats flocks were distributed across the 13 Livestock Farmers Organizations (OPP's) areas. The frequency of seropositive flocks ranged from $4.3 \%$ in Miranda e Vimioso to $14.9 \%$ in Carrazeda e Vila Flor (table 2).

All variables of individual seroprevalence had significant differences $(\mathrm{P}<0.001)$. The animals of medium flocks ( $>30$ and $\leq 150$ animals) presented higher seroprevalences $(0.50 \%)$ than the animals in smaller or larger flocks (both with $0.37 \%$ ). The seroprevalence of animals showed a higher seroprevalence in goats $(0.75 \%)$ than in sheep $(0.38 \%)$. The individual seroprevalence values among animals from herds with only one specie (sheep or goat) $(0.37 \%)$, and herds with both species $(0.71 \%)$ were significantly different $(\mathrm{P}<0.001)$. The seroprevalence in animals which producing meat was significantly higher than the ones producing milk $(\mathrm{P}=0.002), 0.46 \%$ and $0.36 \%$, respectively (table 3 ). The individual serological survey (table 4) distributed across all OPP's of the Northeast of Portugal (13) showed significant differences $(\mathrm{P}<0.001)$. The lowest individual value of seroprevalence in flocks (0.08\%) was found in Miranda e Vimioso, and the highest value was found in Tarouca (1.5\%).

\section{DISCUSSION}

Seroprevalence knowledge is one of the cornerstone of surveillance and monitoring programmes, because it is decisive on whether to implement control measures or not, and provides data for the evaluation of the efficacy of these measures and it is the basis for modification (Mousing et al 1997).

This is the first epidemiological study that describes seroprevalence of brucellosis in Northeast of Portugal and there are few recent epidemiological studies conducted in Europe (Lithg-Pereira et al 2004, Coelho et al 2007). The aim of this study was to characterize the sheep and goat brucellosis prevalence by herd size, species, constitution of the herd and type of production, using used only animals and flocks with this information properly registered. In Portugal, between 1990 and 2004, the prevalence of individual animals decreased from $3.5 \%$ to $0.8 \%$. In flocks, prevalence decreased from $12.2 \%$ to $2.8 \%$ (Vaz 2005). The individual seroprevalence in Trás-os-Montes e Alto Douro in 2007 was smaller than the described values although the seroprevalence in flocks was higher.

The results of this study are in agreement with previous studies, where brucellosis was associated with large herd size (Kabagambe et al 2001, Al-Majali 2005, Coelho et al 2007). Larger herds were more likely to have at least one positive goat than smaller herds and were usually associated with mass management practices that are typically more difficult to control and allow for closer contact between animals and their environment, which increases the potential for exposure to infectious excretions (Al-Majali 2005). Our results could also be related to a higher density of animals per flock. Stocking density allows greater contact between animals. This creates a higher bacterial load in the environment, and hence the chances of disease transmission will be increased. Other explanation might be due to the fact that grazing in communal pastures may facilitate the contact between infected and not infected flocks (Kabagambe et al 2001, Al-Talafhah et al 2003). This situation probably occurs more frequently in larger flocks, because of their size. The small herds are generally more isolated (Lithg-Pereira 2001) and generally use tethering or a zero-grazing system (Kabagambe et al 2001), therefore the animals do not have this contact.

Another interesting result of our study is that individual seroprevalence was significantly higher in goats than in sheep. Our results are consistent with others reported by Sobhani-Motlagh et al (2005), who found that goats are more susceptible to the infection than sheep. However, these results are in contrast with Reviriego et al (2000). A plausible explanation for this finding is difficult because ovine behaviour that get together in parturition or at night (long-term close contact), increases potential of disease transmission, and goats do not have this behaviour (European Commission 2001).

Results of this study showed a significantly higher individual and flock seroprevalence in mixed herds. Kabagambe et al (2001) and Ocholi et al (2004) found similar results. Our results support the hypothesis that keeping sheep in contact with goats is a risk factor for brucellosis.

Although numerous authors have reported that brucellosis is more prevalent in milk than in meat herds (Omer et al 2000, Lithg-Pereira 2001), in this study a higher seroprevalence was found in meat animals. These results are difficult to explain and could be related with a better sanitary management of milk herds in the region because the milk is used to make traditional high quality cheese, which is made with certified milk. Other explanation could be that, in meat herds, animals are more often introduced into the herd, and that practice increases the risk of introducing infected animals (Omer et al 2000).

The estimation prevalence recorded in the 13 OPP's indicated that Brucella infection was widespread in small ruminants throughout the region.

Information on the prevalence of sheep and goats brucellosis infection is necessary to define control measures for zoonotic brucellosis (Godfroid et al 2005). The results of this study are useful for policy makers. A coherent control program should combined mass vaccination, with serological tests and a slaughter strategy.

\section{ACKNOWLEDGEMENTS}

The authors thank to M.A. Armada Nunes, F. Martins, F. Neto and A.P. Figueiras, from the Agricultural Services, and to S. Quintans, R. Valentim and A. Pina Fonseca from the Central Services of Veterinary. The work was supported by the strategic 
research project PEst-OE/AGR/UI0772/2011 financed by the Foundation for Science and Technology (FCT).

\section{REFERENCES}

Al-Majali AM. 2005. Seroepidemiology of caprine brucellosis in Jordan. Small Rumin Res 58, 13-18.

Al-Talafhah A, SQ Lafi, Y Al-Tarazi. 2003. Epidemiology of ovine brucellosis in Awassi sheep in Northern Jordan. Prev Vet Med 60, 297-306.

Alton GG, LM Jones, RD Angus, JM Verger. 1988. Techniques for the brucellosis laboratory. Institut National de la Recherche Agronomique, Paris, France.

Benkirane A. 2006. Ovine and caprine brucellosis: World distribution and control/ eradication strategies in West Asia/ North Africa region. Small Rumin Res 62, 19-25.

Cassataro J, K Pasquevich, L Bruno, JC Wallach, CA Fossati, PC Baldi. 2004. Antibody reactivity to Omp31 from Brucella melitensis in human and animal infections by smooth and rough Brucellae. Clin Diagn Lab Immunol $11,111-114$.

Coelho AM, AC Coelho, M Roboredo, J Rodrigues. 2007. A case-control study of risk factors for brucellosis seropositivity in Portuguese small ruminants herds. Prev Vet Med 82, 291-301.

Erdenebaatar J, B Bayarsaikhan, A Yondondorj, M Watarai, T Shirahata, E Jargalsaikhan, K Kawamoto, S Makino. 2004. Epidemiological and serological survey of brucellosis in Mongolia by ELISA using sarcosine extracts. $\mathrm{Mi}$ crobiol Immunol 48, 571-577.

European Commission. 2001. Brucellosis in sheep and goats (Brucella melitensis). Scientific Committee on Animal Health and Animal Welfare. SANCO.C.2/AH/R23/2001. Pp 89.

Garin-Bastuji B, J-M Blasco, C Marín, D Albert. 2006. The diagnosis of brucellosis in sheep and goats, old and new tools. Small Rumin Res 62, 63-70.
Godfroid J, A Cloeckaert, J-P Liautard, S Kohler, D Fretin, K Walravens, B Garin-Bastuji, J-J Letesson. 2005. From the discovery of the Malta fever's agent to the discovery of a marine mammal reservoir, brucellosis has continuously been a re-emerging zoonosis. Vet Res 36, 313-326.

Kabagambe EK, PH Elzer, JP Geaghan, J Opuda-Asibo, DT Scholl, JE Miller. 2001. Risk factors for Brucella seropositivity in goat herds in Eastern and Western Uganda. Prev Vet Med 52, 91-108.

Lithg-Pereira PL. 2001. Epidemiología de brucelosis ovina y caprina en la Provincia de León. Tesis de Doctorado, Facultad de Veterinaria, Universidad de León, León, España.

Lithg-Pereira PL, FA Rojo-Vázquez, RC Mainar-Jaime. 2004. Case-control study of risk factors for high within-flock small-ruminant brucellosis prevalence in a brucellosis low-prevalence area. Epidemiol Infect 132, 201-210.

Mousing J, PT Jensen, C Halgaard, F Bager, N Feld, B Nielsen, JP Nielsen, S Bech-Nielsen. 1997. Nationwide Salmonella enterica surveillance and control in Danish slaughter swine herds. Prev Vet Med 29, 247-261.

Neto FG, Y Vaz. 2002. Conjuntival Rev. 1 vaccination of adult sheep and goats in Trás-os-Montes, Portugal. Epidémiol et Santé Anim 42, 99-107.

Nielsen K. 2002. Diagnosis of Brucellosis by Serology. Vet Microbiol 90, 447-459.

Ocholi RA, JKP Kwaga, I Ajogi, JO Bale. 2004. Phenotypic characterization of Brucella strains isolated from livestock in Nigeria. Vet Microbiol 103, 47-53.

O'Leary S, M Sheahan, T Sweeney. 2006. Brucella abortus detection by PCR assay in blood, milk and lymph tissue of serologically positive cows. Res Vet Sci 81, 170-176.

Omer MK, E Skjerve, Z Woldehiwet, G Holstad. 2000. Risk factors for Brucella spp. infection in dairy cattle farms in Asmara, State of Eritea. Prev Vet Med 46, 257-265.

Reviriego FJ, MA Moreno, L Domínguez. 2000. Risk factors for brucellosis seroprevalence of sheep and goat flocks in Spain. Prev Vet Med 44, 167-173. 